\title{
Carbon dioxide measurement in Irish blanket peatlands: An assessment of pool-soil flux variability
}

\author{
Mariya Radomski \\ Technological University Dublin, mariya.radomski@tudublin.ie \\ Alan Gilmer \\ Technological University Dublin, alan.gilmer@tudublin.ie \\ Vivienne Byers \\ Technological University Dublin, vivienne.byers@tudublin.ie
}

See next page for additional authors

Follow this and additional works at: https://arrow.tudublin.ie/ehsiart

Part of the Climate Commons, Environmental Health and Protection Commons, Hydrology Commons, Medicine and Health Sciences Commons, Soil Science Commons, and the Water Resource Management Commons

\section{Recommended Citation}

Mariya Radomski, Alan Gilmer, Vivienne Byers, Eugene McGovern, Carbon dioxide measurement in Irish blanket peatlands: An assessment of pool-soil flux variability, Ecohydrology \& Hydrobiology, Volume 19, Issue 4, 2019, Pages 487-498, ISSN 1642-3593, DOI: 10.1016/j.ecohyd.2019.02.001.

This Article is brought to you for free and open access by the ESHI Publications at ARROW@TU Dublin. It has been accepted for inclusion in Articles by an authorized administrator of ARROW@TU Dublin. For more information, please contact arrow.admin@tudublin.ie, aisling.coyne@tudublin.ie,gerard.connolly@tudublin.ie.

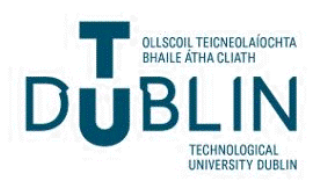




\section{Authors}

Mariya Radomski, Alan Gilmer, Vivienne Byers, and Eugene McGovern

This article is available at ARROW@TU Dublin: https://arrow.tudublin.ie/ehsiart/30 


\title{
Carbon dioxide measurement in Irish blanket peatlands: An assessment of pool-soil flux variability
}

\author{
Mariya Radomski ${ }^{\mathrm{a}, \mathrm{b}, *}$, Alan Gilmer ${ }^{\mathrm{a}, \mathrm{b}}$, Vivienne Byers ${ }^{\mathrm{a}, \mathrm{c}}$, Eugene McGovern ${ }^{\mathrm{d}}$

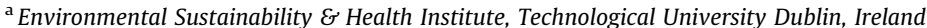 \\ ${ }^{\mathrm{b}}$ College of Engineering $\mathcal{E}$ Built Environment, Technological University Dublin, Ireland \\ ${ }^{c}$ College of Business, Technological University Dublin, Ireland \\ d School of Surveying E Construction Management, Technological University Dublin, Ireland
}

\section{A R T I C L E I N F O}

\section{Article history:}

Received 10 January 2018

Received in revised form 16 January 2019

Accepted 2 February 2019

Available online 10 February 2019

\section{Keywords:}

Carbon

Climate

Soil

Temperature

Water

\begin{abstract}
A B S T R A C T
Peatlands have been recognised as having a significant role in the mediation of atmospheric carbon dioxide $\left(\mathrm{CO}_{2}\right)$ levels with direct implications for global climate change. Longitudinal in situ measurement systems for $\mathrm{CO}_{2}$ concentrations in blanket peatland ecosystems are difficult to implement where the nature of terrestrial-aquatic connectivity and hydrodynamics have a significant effect on the carbon cycle. The need for greater data on $\mathrm{CO}_{2}$ concentrations and flux monitoring in these settings has been well recognised. However, applying the most appropriate monitoring approach presents a special challenge. This paper sets out the development of a direct method for field based longitudinal $\mathrm{CO}_{2}$ concentration measurement. Based on experiential considerations a new approach is presented that addresses the complexity associated with the high diurnal dynamics of $\mathrm{CO}_{2}$ evasion during mid-winter in an Irish blanket peatland soil-water system. The paper outlines the significance of a direct in situ continuous measurement strategy using a nondispersive infrared (NDIR) sensor to evaluate $\mathrm{CO}_{2}$ concentrations. The $\mathrm{CO}_{2}$ concentrations recorded as part of this study showed significant differences between the pond waters and the peat waters. The overall $\mathrm{CO}_{2}$ concentration trend did not correlate with the temperature patterns. Further monitoring is essential to evaluate the spatial and longitudinal trends in carbon dynamics. Outputs of this study will have a direct bearing on approaches to carbon flux determinations for this landscape type and will provide an important input to future efforts to explore carbon-hydrodynamics in the surface and subsurface waters of blanket peatlands.
\end{abstract}

(C) 2019 European Regional Centre for Ecohydrology of the Polish Academy of Sciences. Published by Elsevier B.V. All rights reserved.

\section{Introduction}

\subsection{Blanket peatlands and hydrodynamics}

Peat is a biogenic deposit which has predominantly developed in the current interglacial period of the Holocene

\footnotetext{
* Corresponding author at: Environmental Sustainability \& Health Institute, Technological University Dublin, Ireland.

E-mail address: mariya.radomski@mydit.ie (M. Radomski).
}

(Hammond, 1981). Peat accumulates under conditions of impeded drainage and $\mathrm{O}_{2}$ (oxygen) deficiency in areas where the rate of plant production exceeds the rate of plant decomposition (Feehan and O'Donovan, 1996). Peatlands are a type of terrestrial wetland ecosystem that arises where land areas are saturated with water and precipitation inundation is sufficient in frequency and duration to support the ecosystem's unique vegetation (Otte, 2003). It has been estimated that there are about 4.5 million $\mathrm{km}^{2}$ of peatland globally (Amundson, 2001; Otte, 2003; Schulze and Freibauer, 2005; Bullock et al., 2012; Turner et al., 
2013). These peat deposits are storing approximately 400 billion tons of peat which represents between onethird and one-half of the world's soil carbon pool (Amundson, 2001; Otte, 2003; Holden, 2005; Schulze and Freibauer, 2005; Bullock et al., 2012; Turner et al., 2013). The scale and long-term ability of these peatlands to store carbon and mediate $\mathrm{CO}_{2}$ levels within the atmosphere represents a crucial component in global climatic biosphere feedback systems and hence underscores the importance of understanding the volumes and pathways of carbon dynamics and $\mathrm{CO}_{2}$ efflux arising from these soil-ecosystems. However, global estimates of the annual net release of $\mathrm{CO}_{2}$ from this soil-ecosystem landscape component remains uncertain particularly when compared to other elements in the global carbon budget (Le Quéré et al., 2009).

Given the scale and dynamics of water within the peatland ecosystems it is not surprising that much of the evasion of carbon in these ecosystems is mediated by hydro-dynamic processes including the translocation of dissolved $\mathrm{CO}_{2}$, dissolved organic carbon (DOC), dissolved inorganic carbon (DIC) and the rate and location of $\mathrm{CO}_{2}$ diffusion (Raymond et al., 2013; Leith et al., 2015). This study explores the contribution of $\mathrm{CO}_{2}$ evasion from the lentic waters and soils of blanket peatlands. Blanket bogs initially develop in discrete locations which ultimately coalesce into a widespread peat landscape ranging in depth from 2 to $8 \mathrm{~m}$ (Feehan and O'Donovan, 1996). In general, this peat type follows the underlying topography except on very steep slopes. The stratigraphy of these peatlands is typically considered with reference to the diplotelmic system which comprises an upper, periodically aerated, and partly living soil layer (acrotelm) and a lower anaerobic layer (catotelm) where metabolic activity is greatly reduced (Holden and Burt, 2003). The general flow pattern of water in these peatlands is horizontal on or near the surface and through the upper layers of peat at the top of the water table (Lindsay, 1995). This flow pattern is highly variable and often produces surface ponds and hollows where water movement is greatly reduced. Flow in the catotelm is much less and is often characterised as minor in terms of contributions to overall flow (Lindsay, 1995). However, the existence of larger matrix channels, macropores and soil pipes within the catotelm means that a significant portion of water transport in blanket peats can be quite rapid even in deeper peat layers. Soil-water $\mathrm{CO}_{2}$ efflux is a major component of the biosphere's carbon cycle and has been estimated to contribute up to three-quarters of total ecosystem respiration (Law et al., 2002). This underscores the importance of understanding the nature and source of $\mathrm{CO}_{2}$ generation in this significant ecosystem type.

\subsection{Water- $\mathrm{CO}_{2}$ evasion in blanket peatlands}

A major issue for water quality control in recent years has been the rising trend in the concentration of DOC from peatland catchments. The doubling of levels of DOC (and the associated discolouration of water) has been identified as one of the single largest changes in upland water quality (Worrall et al., 2003; Labadz et al., 2010). Indeed, the transport of carbon through the labyrinth of hydraulic pathways that characterise blanket peatland settings represents a significant component affecting regional carbon balances including the efflux of $\mathrm{CO}_{2}$ into the atmosphere (Dinsmore et al., 2011; Fasching et al., 2014; Yang et al., 2015; Ruhala and Zarnetske, 2017). Since water is strongly associated with the control and transport of carbon (organic and inorganic; dissolved and particulate) it is important to understand the associated hydrodynamics of these systems (Wallin et al., 2011, 2013; Whitfield et al., 2011). As the sources of $\mathrm{CO}_{2}$ vary in space and time, measurement of $\mathrm{CO}_{2}$ concentrations in peatland surface water systems represents a key contribution to overall carbon cycle determinations. Measurements in this area are of interest to researchers from a range of disciplines concerned with the biogeochemistry, ecology and hydrology of wetlands, ponds, streams and lakes (Battin et al., 2008; Bodmer et al., 2016). It is also a parameter of interest in addressing questions on the terrestrial-aquatic connectivity of groundwater and surface water and the carbon cycle in general (Cole et al., 2007).

\subsection{Approaches to the measurement and monitoring of $\mathrm{CO}_{2}$ in peatlands}

The longitudinal evaluation of $\mathrm{CO}_{2}$ dynamics in the waters within the lentic-lotic continuum of peatland settings is problematic. The ephemeral and intermittent nature of ponds, pools and streams that flow in rills and gullies across the peatland landscape coupled with the high variability in water flow rates within peatland ecosystems makes long term monitoring of dissolved $\mathrm{CO}_{2}$ patterns a precarious endeavour. Various approaches have been applied over the years to evaluate the efflux of $\mathrm{CO}_{2}$ from freshwater systems. However, efforts have been largely limited to either making spot measurements based on direct extraction and testing (Kling et al., 1991; Hope et al., 1995) or based on indirect estimates of the dissolved $\mathrm{CO}_{2}$ concentration from measurements of other parameters including $\mathrm{pH}$ and alkalinity (Neal et al., 1998). Johnson et al. (2010) set out a new approach to the continuous direct in situ measurement of $\mathrm{CO}_{2}$ efflux from freshwaters using an infra-red gas analysis. The nondispersive infra-red (NDIR) sensor technique has, in one form or another, been in use since the 1930s (Choi and Son, 2011). However, changes in the application systems, including power source, probe size, etc. now mean that it is possible to utilise this technique in remote settings. This study has sought to address the challenge of the long-term measurement of peatland $\mathrm{CO}_{2}$ efflux values through the development of a robust and adaptive installation system using NDIR technologies sampling pools and the waters of the peat soil immediately adjacent to the pools. The set-up proposes a unique installation for the soil water probes that affords high dynamic flexibility with variation in water table depth and a site monitoring configuration targeting a profile of the micro habitats.

\section{Materials and methods}

\subsection{The study site}

The study area was in an extensive upland blanket peatland area within the Wicklow Mountains, County 
Wicklow, Ireland. This blanket peatland represents a significant mire ecosystem ranging from 15 to $30 \mathrm{~km}$ in width and stretching for more than $40 \mathrm{~km}$ in a north-south direction (Fig. 1) (Aalen et al., 2011). This study was located on Liffey Head Bog which is located within the Wicklow Mountains National Park one of the largest national parks in Ireland. This upland blanket peatland is a site of international importance and a conservation area managed by the Irish National Parks and Wildlife Service (National Parks and Wildlife Service, 2017). It is an actively growing peatland and it has numerous pools and hollow microforms which are inhabited by a wide range of organisms (Conaghan et al., 2000). Pools within these peatland ecosystems are typically characterised as environments with greater organic carbon production than microbial mineralisation (Uhlmann et al., 2011). The perennial nature of these pools and the prevalence of slow and incomplete decomposition processes are favoured under surplus water availability from the atmosphere (precipitation) and from the surrounding terrestrial zone (run-off) coupled with low oxygen availability - a environment which should lead to net carbon sequestration, net peat accumulation and siltation (Uhlmann et al., 2011).

Within the Wicklow Mountains and the Liffey Head bog a suitable study site was selected on the interfluve of the valleys of the adjacent headwaters, i.e. the dividing region between the catchments of the Dargle River, the Liffey River and the Cloghoge River (Fig. 1). This interfluve has an approximate width of $200 \mathrm{~m}$. The precise location $\left(53^{\circ} 09.181^{\prime} \mathrm{N}, 06^{\circ} 16.988^{\prime} \mathrm{W}\right)$ was selected based on parameters such as micro-topography, including a regular hummock-hollow-pool profile, and hydromorphological characteristics deemed representative of the wider peatland ecosystem in the region. The selection of these contrasting micro-characteristics is consistent with the approach advocated by Claire Horner-Devine et al. (2003). The study was undertaken over a three-week period in December 2016 to establish mid-winter values for this component of the $\mathrm{CO}_{2}$ carbon cycle in these peatlands. The blanket peatland at the study site is positioned on porphyritic granite and the peat depth ranges from approximately 2.7 to $5 \mathrm{~m}$ in this region (Hannigan et al., 2011). The mean annual precipitation in the area can reach $2000 \mathrm{~mm}$ per annum (Met Eireann, 2017a) and the mean monthly temperature values reported for this region of Ireland range for $2-20^{\circ} \mathrm{C}$ throughout the year (Sweeney, 2014) although microclimatic conditions clearly exist within the Wicklow Mountains and these values will be reduced with altitude.

The peat soil zone was selected as a transition zone between high lawn and low hummock vegetation (Johnson and Damman, 1991; Laiho, 2006). The pools at the study site exhibited characteristic dystrophic properties including the paucity of nutrients and calcium, high acidity and elevated concentrations of dissolved humic materials as typically reported by Uhlmann et al. (2011). The pool waters were clear but overall the pools presented as brownish in colour (Fig. 2). The peat pool area was approximately $100 \mathrm{~m}^{2}$ and had depth of about $1.4 \mathrm{~m}$ although the boundary of a distinct pool bed is difficult to define given the existence of large amounts of soft detrital material (Fig. 2).

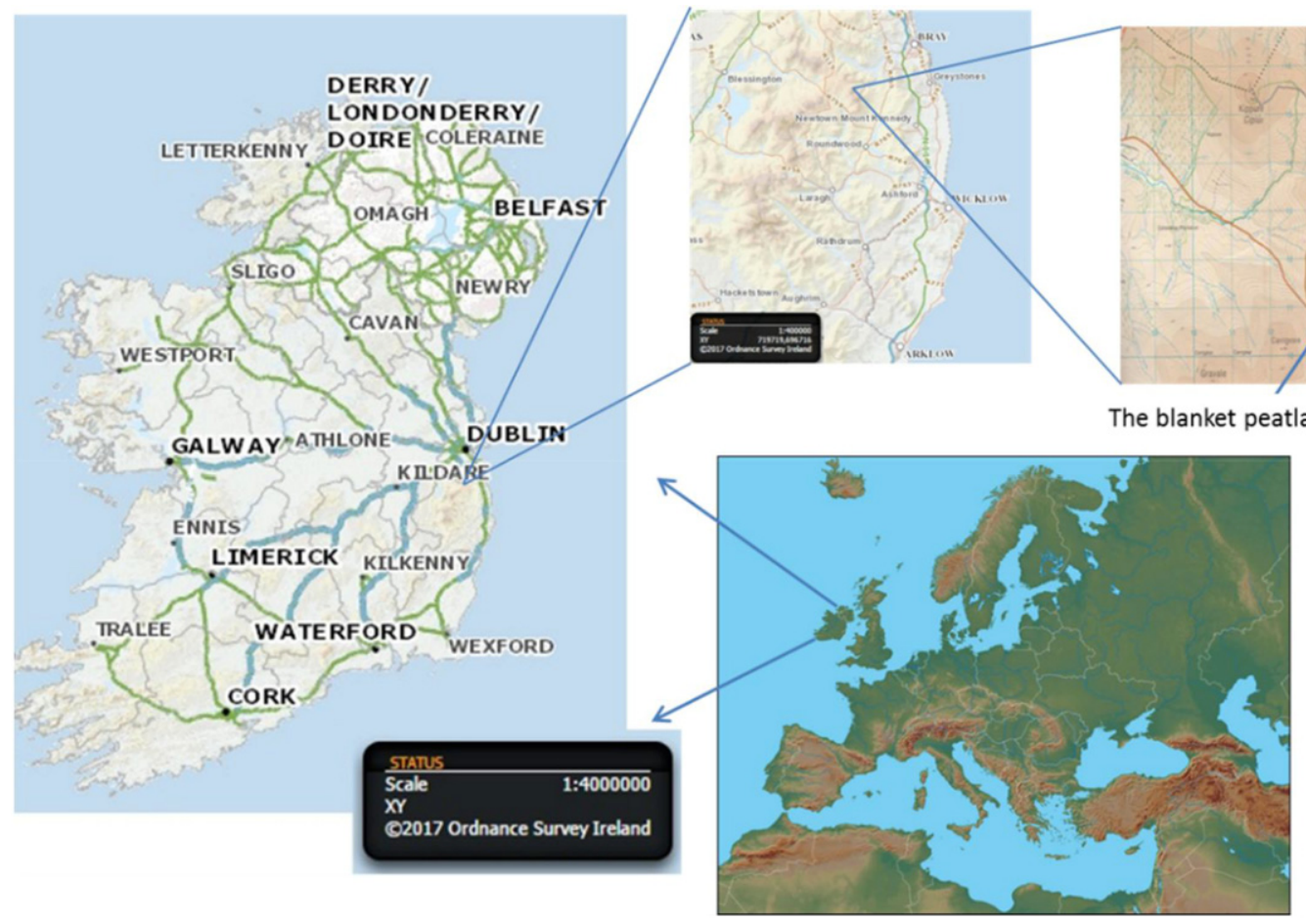

Fig. 1. The location of the study site - east coast of Ireland. Adapted from OSI (2017). 


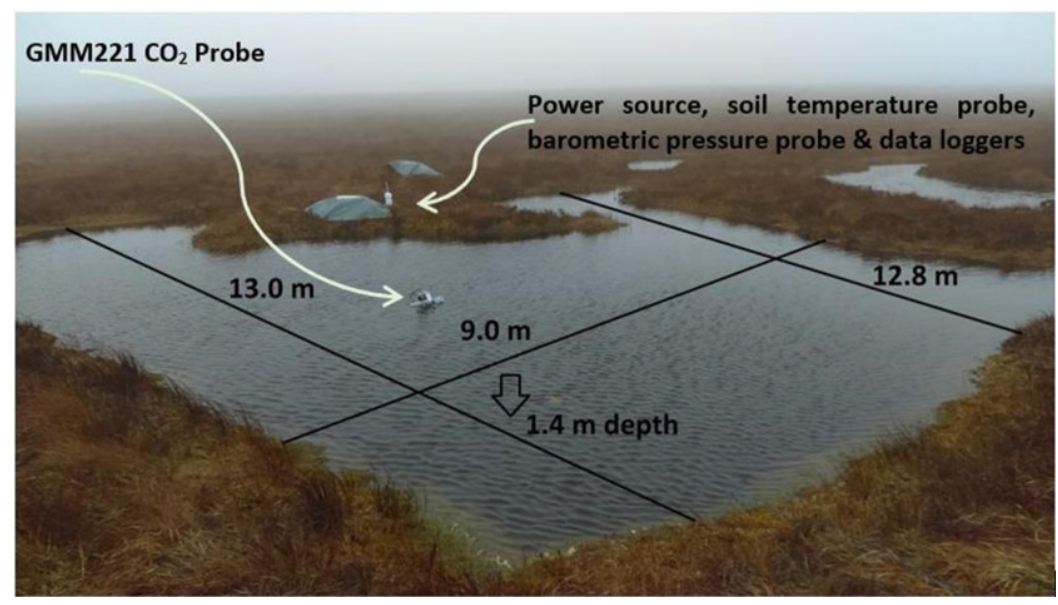

Fig. 2. The $\mathrm{CO}_{2}$ 'Peat-Hydro' monitoring site in the Wicklow Mountains, Ireland.

\subsection{Continuous in situ $\mathrm{CO}_{2}$ efflux measurement}

This approach has been adopted and adapted to the measurement of $\mathrm{CO}_{2}$ concentrations arising from the freshwaters of the blanket peatland pools and the surrounding terrestrial zone. In this study, the sensor of choice was a Vaisala GMM220 CARBOCAP non-dispersive infra-red (NDIR) gas sensor (Fig. 3) (Vaisala, 2012, 2013). Other parameters recorded at the site during the measurement period included water, soil and air temperature and the atmospheric pressure.

The concentration of $\mathrm{CO}_{2}$ is detected when infrared (IR) radiation is emitted from a light source and passes through the sample chamber to the detector - the variation in light intensity is detected and converted into a concentration value (Vaisala, 2012). This system offers several advantages compared to other spectroscopic techniques,

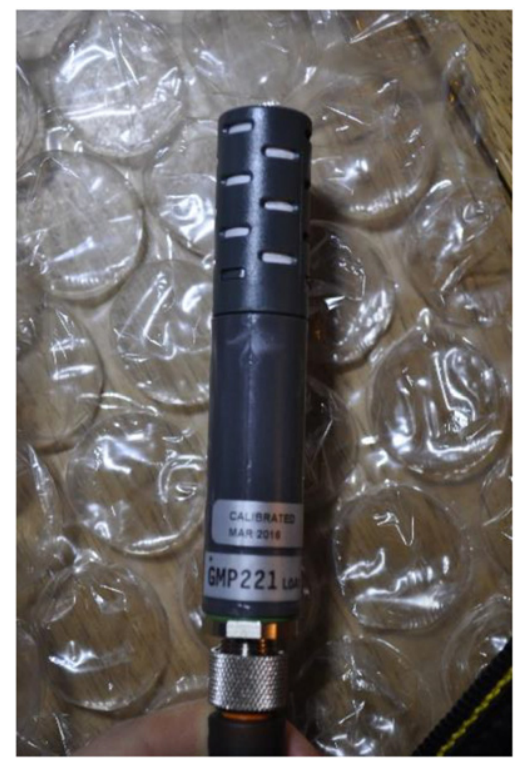

Fig. 3. The Vaisala GMM220 (GMP221 probe model) CARBOCAP sensor. including the relatively low power consumption $(<2.5 \mathrm{~W})$ and its ability to operate at low temperatures (e.g. $-20^{\circ} \mathrm{C}$ ) (Vaisala, 2013). However, there are some limitations, such as interference and detection limit (e.g. $0-10 \%$ or up to $100,000 \mathrm{ppm} \mathrm{CO}_{2}$ ) which may require multiple units where the range to be covered is large (Vaisala, 2013). The Vaisala sensors are shipped with certificates of calibration (Johnson et al., 2010). The checked accuracy of this GMM220 NDIR sensor at $25^{\circ} \mathrm{C}$ and $1012 \mathrm{hPa}$ is $\pm 1.5 \%$ of range $+2 \%$ of reading (applies for concentrations above $2 \%$ of full scale) (Vaisala, 2013). For assessing the accuracy of the sensors after the field exposure, it is appropriate to use the 'field check adapter' which is a chamber for pump-aspirated sampling systems which can be used with calibration gases (Johnson et al., 2010). There is a consistent difference between the individual sensors and standard gases, but these can be illuminated by applying a sensor-specific linear correction factor (Johnson et al., 2010). It also has a short warm-up time of $30 \mathrm{~s}$ ( $15 \mathrm{~min}$ - full specifications) and response time of $20 \mathrm{~s}$ (Vaisala, 2013). Johnson et al. (2010) reported the transfer coefficient $k_{a}$ and diffusivity $D$ of the expanded PTFE membrane for $\mathrm{CO}_{2}$ to be $0.8 \pm 0.1 \mathrm{~cm} \mathrm{~s}^{-1}$ and $0.08 \pm 0.01 \mathrm{~cm}^{2} \mathrm{~s}^{-1}$, respectively. Since diffusion of $\mathrm{CO}_{2}$ in water is about 10,000 times slower than in air the material diffusivity of the PTFE tubing and its transfer coefficient indicate that it presents a negligible barrier to $\mathrm{CO}_{2}$ diffusion and the temporal response of the sensor (Johnson et al., 2010; Scott, 2000). Furthermore the use of the Vaisala sensor has shown high adaptability for robust field applications having been used in a number of lotic environments (Crawford et al., 2014).

The GMM220 sensor type that was used in this study was supplied with DC power $(2 \times 75 \mathrm{Ah}, 12 \mathrm{~V}$ DC batteries deployed in-parallel) (Fig. 4) and the output was recorded with a data acquisition system (Vaisala data-logger; DL4000) (Fig. 4). The sampling interval was every minute. A digital timer was integrated into the circuitry to cycle the sensor on and off for measurements at a reduced frequency to conserve power and enable the system to operate for longer periods in the field before requiring a battery change. 
(a)

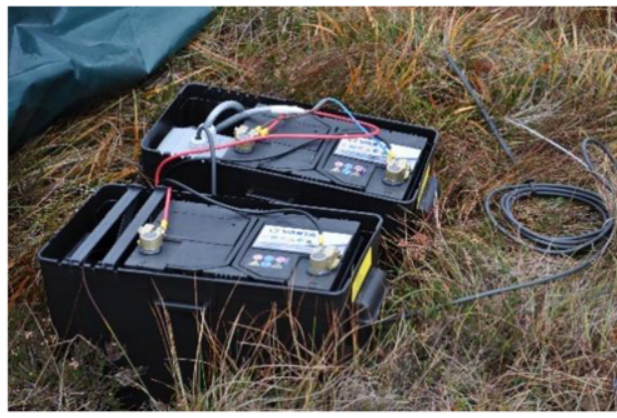

(b)

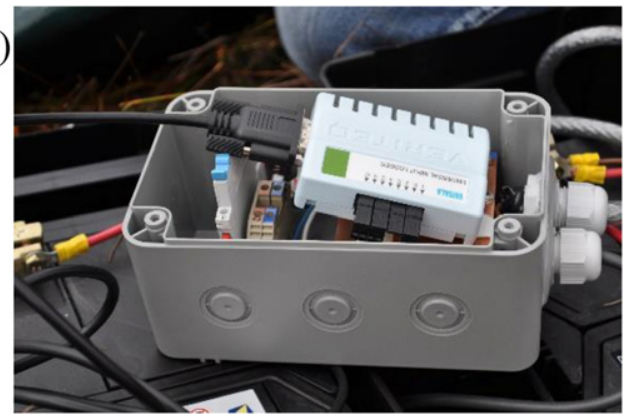

Fig. 4. Equipment used in the study: (a) the battery set-up using $2 \times 75 \mathrm{Ah}, 12 \mathrm{~V}$ DC; and (b) the Vaisala DL4000 data-logger.

\subsection{Pool and peat zone sensor installation}

The Vaisala GMM220 NDIR sensor probes are approximately $20 \mathrm{~mm}$ in diameter by $150 \mathrm{~mm}$ long. These sensors are not suitable for direct deployment in aqueous solutions and need to be modified. The modification consists of using a protective expanded polytetrafluoroethylene (PTFE) tube sleeve that is highly permeable to $\mathrm{CO}_{2}$ but impermeable to water. The PTFE sleeves were sealed using Plasti Dip rubberising compound which makes both the cable end and non-cable end of the sensors impermeable to water (Fig. 5).

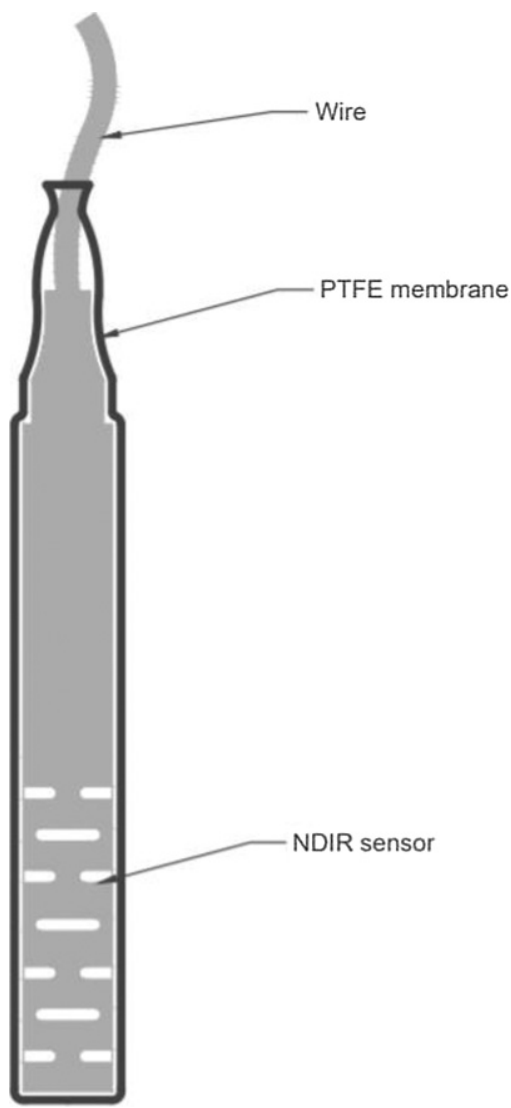

Fig. 5. The Vaisala GMM220 NDIR sensor probe with the PTFE membrane attached.
The pool sensor was fixed inside and in line with the long axis of a perforated $500 \mathrm{~mm} \times 100 \mathrm{~mm}$ PVC pipe. A mesh was then attached to the bottom end of the PVC pipe in to protect the sensor and PTFE sleeve from any potential impact damage from debris when in the field setting. The pool sensor and its protective PVC pipe were then secured in the middle of the pool with floats to ensure that the probe sat vertically and was held at a constant depth within the water (Fig. 6).

The peat soil conditioned sensor was similarly attached in line with the long axis of a perforated PVC pipe although in this case the pipe was longer $(1000 \mathrm{~mm} \times 100 \mathrm{~mm})$. In this soil-based installation the perforated PVC pipe was fixed in the peatland. A float was attached to the top section of the sensor housing which is free to move independently inside the PVC pipe and the power and data leads were coiled within the upper sections of the pipe (Fig. 6). This procedure was developed to ensure that should the water level inside the PVC pipe change, the sensor assembly would move freely up and down inside the protective perforated PVC piping and so maintain a constant depth with reference to the water table of the peat. This sensor unit was placed in an $800 \mathrm{~mm}$ deep well excavated in the peat using an Edelman auger. The top $200 \mathrm{~mm}$ of the PVC pipe was left protruding above the surface of the peat soil and the open end of the pipe was covered to protect the sensor and PTFE sleeve from the ingress of debris (Fig. 5).

\subsection{The integration of temperature and atmospheric pressure}

The GMM220 NDIR Vaisala CARBOCAP sensor used in this study does not measure pressure and temperature and therefore could not automatically compensate for changes in atmospheric pressure and temperature variations. To compensate for these components in the system it was necessary to measure the atmospheric pressure and temperature components on site. Atmospheric pressure was measured using a UNI-T UT330C USB data logger barometric probe which was placed at the pool bank $100 \mathrm{~mm}$ above ground level. Water temperature was recorded using a НOBO Pendant temperature data logger (UA-001-08) placed circa $100 \mathrm{~mm}$ below the surface of the pool water, a second logger was placed about $100 \mathrm{~mm}$ above ground level to record air temperature and a third temperature logger was placed approximately $50 \mathrm{~mm}$ 
(a)

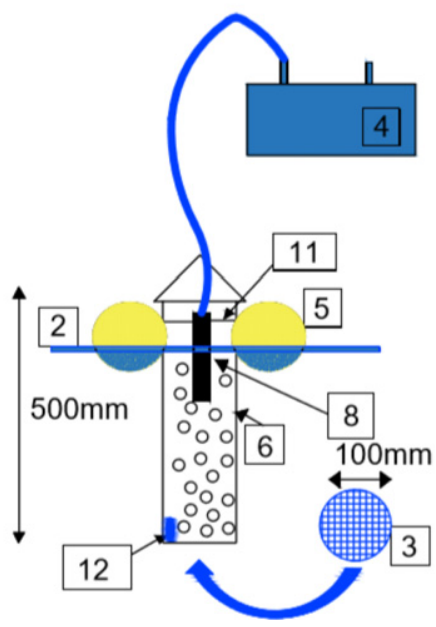

(b)

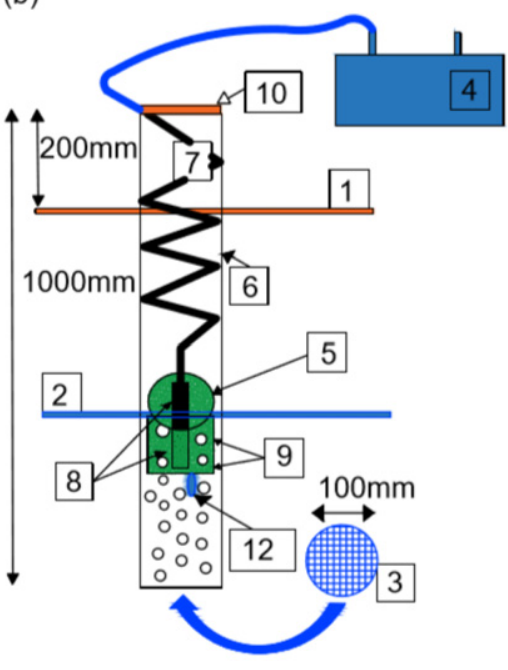

Fig. 6. NDIR module transmitter: component board, cable and a $\mathrm{CO}_{2}$ probe for field installation (a) pool assembly and (b) peat zone assembly - components labeled 1-12 (1 Land surface, 2 Water surface, 3 Mesh-net, 4 Transmitter, data-logger, switch \& timer, 5 Float assembly, 6 Perforated PVC pipe, 7 Coiled cable \& power line, 8 NDIR sensor, 9 Inner perforated protective housing, 10 Sealing lid, 11 Sensor fastening cables, 12 Water temperature probe).

below the peat-soil surface to record near-surface ground temperature. These parameters were measured on an hourly basis throughout the study period.

\subsection{Theory and calculation}

To calibrate the GMM220 NDIR pool and peat-based sensor outputs it was necessary to adjust for the partial pressure of $\mathrm{CO}_{2}\left(\mathrm{pCO}_{2}\right)$ based on the recorded changes in temperature and total atmospheric pressure (Baehr and DeGrandpre, 2004; Dinsmore, 2008). This approach is based on Henry's universal gas law and states that the mass of a gas that dissolves in a defined volume of water is directly proportional to the pressure of the gas as long as the gas does not react with the water: $C_{\text {gas }}=K_{h} \times P_{\text {gas }}$ (Plummer and Busenberg, 1982). In this equation, $C_{\text {gas }}$ is the concentration of the dissolved gas, $K_{h}$ is Henry's law constant that is temperature dependent (e.g. increases with temperature) and is particular for the specific gas, and the variable $P_{\text {gas }}$ which is the partial pressure of the gas above the solution (Plummer and Busenberg, 1982). Based on this law and the instrumental specifications for the Vaisala sensor, $\mathrm{CO}_{2}$ concentrations were corrected using the following formula: $C_{c}=C_{m}-C_{T}-C_{p}$ (Tang et al., 2003). In this equation, $\mathrm{CO}_{2}$ concentrations $(C)$ were expressed in $\mu \mathrm{mol} \mathrm{mol}^{-1}$, and the subscripts $c, m, T$ and $p$ designate; corrected, measured, temperature-corrected and pressure- corrected respectively (Tang et al., 2003). The temperature correction was calculated using the formula: $C_{T}=14000\left(K_{T}-K_{T}^{2}\right)\left[\frac{25-T_{C}}{25}\right]$ (Tang et al., 2003). In this formula, $T_{C}$ is the temperature $\left({ }^{\circ} \mathrm{C}\right), \quad K_{T}=A_{o}+A_{1} \times C_{m}+A_{2} \times C_{m}^{2}+A_{3} \times C_{m}^{3}, \quad A_{o}=3 \times 10^{-3}$, $A_{1}=1.2 \times 10^{-5}, A_{2}=-1.25 \times 10^{-9}$ and $A_{3}=6 \times 10^{-14}$ (Tang et al., 2003). The pressure correction was calculated using the formula: $C_{P}=K_{P}\left[\frac{P-101.3}{101.3}\right]$ (Tang et al., 2003). In this equation, $P$ is the pressure $(\mathrm{kPa}), K_{P}=A \times C_{m}$ and $A=1.38$
(Tang et al., 2003). The reference pressure and temperature values for the GMM220 were $101.3 \mathrm{kPa}$ and $25^{\circ} \mathrm{C}$. Using the data gathered by the barometric logger and the water and water-soil temperature loggers the appropriate corrections were made to the 'raw' data recorded.

\section{Results}

\subsection{Temperature and atmospheric pressure}

This study sought to investigate the winter level of dissolved $\mathrm{CO}_{2}$ effluxing from a designated pool and peat soil adjacent to it in a blanket peatland in the Wicklow Mountains as knowledge of the carbon dynamics in these ecosystems has a direct bearing on overall atmosphere $\mathrm{CO}_{2}$ efflux rates and carbon translocation within this landscape type. The investigation took place during the month of December when light levels were at their lowest and photosynthetic activity and respiration levels minimal. Air temperatures during the measurement period were cool but not unusual for this temperate maritime climatic region. The values were consistent with the average reported local air temperature for December of $5.4^{\circ} \mathrm{C}$ (Met Eireann, 2017b) and the elevation of the particular location within the Wicklow Mountains. Actual air temperatures during the measurement period ranged from $-3{ }^{\circ} \mathrm{C}$ to $10^{\circ} \mathrm{C}$, while water temperature and soil temperature profiles tended to follow the overall pattern of air temperature which is to be expected as these values are substantially driven by air temperature values (Fig. 7). A correlation analysis of the data sets gives a value of 0.427 for air:water temperature and 0.731 for air:soil temperature.

Atmospheric pressure values at the study site were recorded during the same period that the $\mathrm{CO}_{2}$ values were measured to facilitate adjustment for the effects of partial 


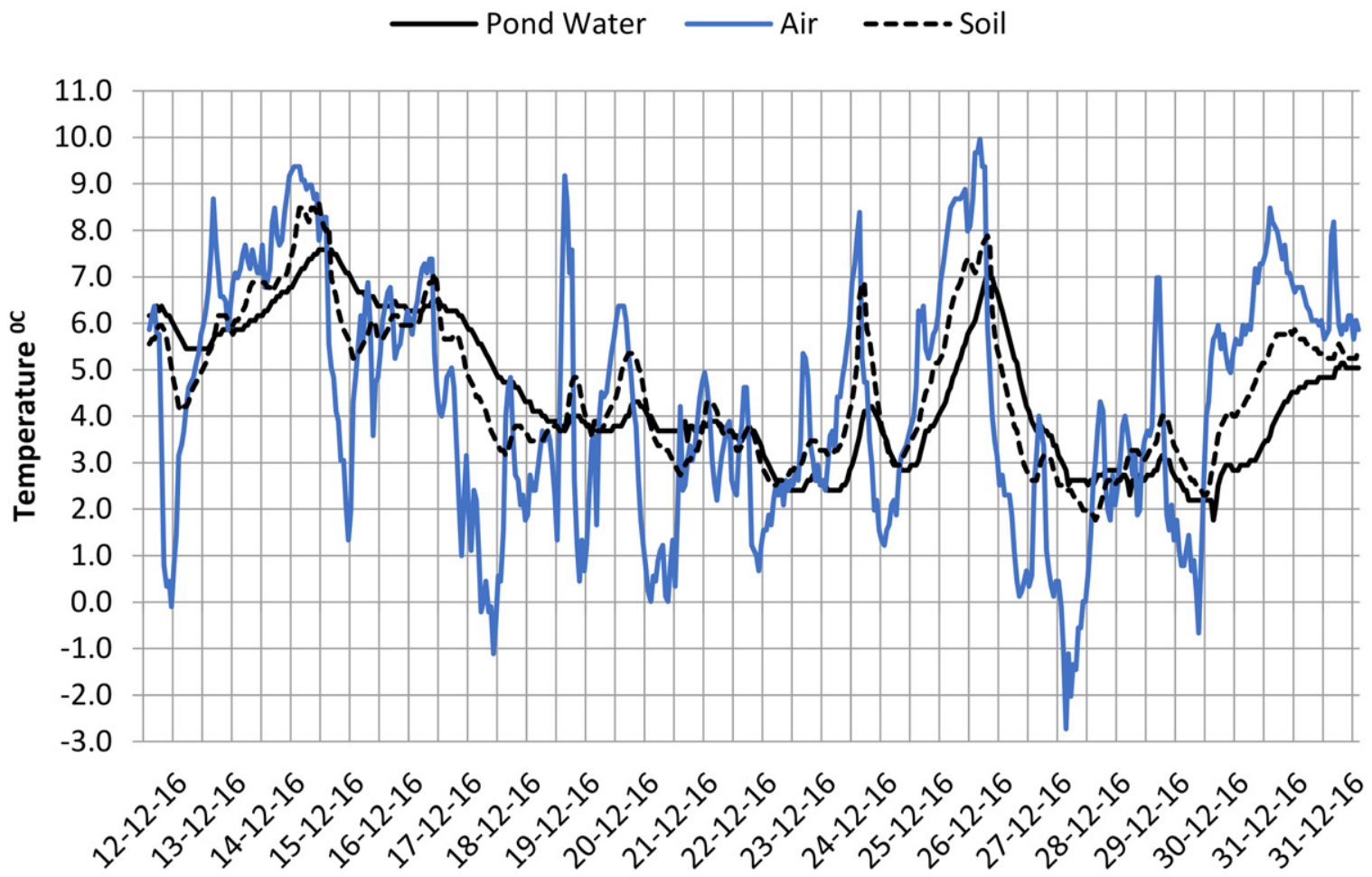

Fig. 7. The range in water, soil and air temperatures over the measurement period.

pressure. Total atmospheric pressure values at the site for the period concerned ranged from 943 to $973 \mathrm{hPa}$ and showed a largely stable period during the initial phase of the study followed by an irregular drop in pressure and then a rise, which began to fall back again towards the end of the measurement period.
3.2. $\mathrm{CO}_{2}$ concentrations in the peatland pool

The concentration of dissolved $\mathrm{CO}_{2}$ in the pool was recorded over a period of three weeks and outputs indicate that the $\mathrm{CO}_{2}$ concentrations ranged from approximately $710 \mu \mathrm{mol} \mathrm{mol}^{-1}$ to a peak of $1560 \mu \mathrm{mol} \mathrm{mol}^{-1}$ (Fig. 8). The

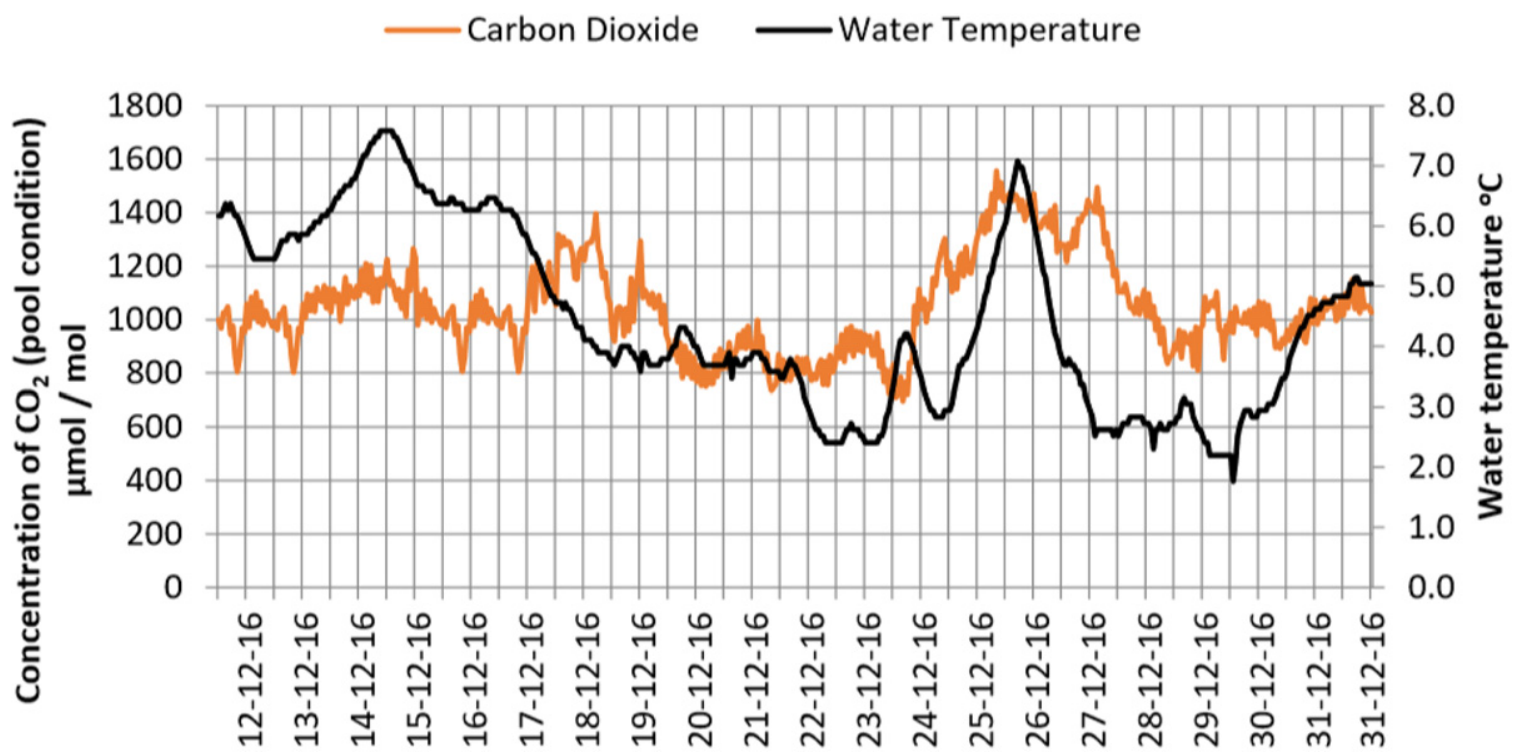

Fig. 8. Corrected $\mathrm{CO}_{2}$ concentrations (pool condition) $\mu \mathrm{mol} \mathrm{mol}{ }^{-1}$. 
average dissolved $\mathrm{CO}_{2}$ concentration for the pool was $1046 \mu \mathrm{mol} \mathrm{mol}^{-1}$. Water is the solvent in which the $\mathrm{CO}_{2}$ dissolves and is also the medium through which temperature values affect the ability of $\mathrm{CO}_{2}$ to dissolve consequently the temperature of water is the most significant thermal component in modifying the recorded dissolved $\mathrm{CO}_{2}$ values. Temperature is also regarded as a significant control on microbial $\mathrm{CO}_{2}$ emissions. Consequently, temperature is also shown (Fig. 8) as an indication of the possible influence this abiotic parameter may have on the $\mathrm{CO}_{2}$ values measured. It is also interesting to note that the correlation coefficient of the water temperature and the reported $\mathrm{CO}_{2}$ values over the measurement period shows a weak positive coefficient of 0.248 .

\section{3. $\mathrm{CO}_{2}$ concentrations in the peatland soil}

The peat soil zone studied is a region of the blanket peatland approximately $3 \mathrm{~m}$ from the bank of the pool. The dissolved $\mathrm{CO}_{2}$ values for the waters within the sample well in the blanket peat show much higher levels of dissolved $\mathrm{CO}_{2}$ than that recorded in the pool ranging from 18,000 to $58,000 \mu \mathrm{mol} \mathrm{mol}^{-1}$ (Fig. 9). The dissolved $\mathrm{CO}_{2}$ values in the peat soil condition were recorded over the same period that the values measured in the pool were recorded. The average value for dissolved $\mathrm{CO}_{2}$ in the peat soil was $31,834 \mu \mathrm{mol} \mathrm{mol}^{-1}$. Water temperature data is shown alongside the $\mathrm{CO}_{2}$ data for the same reasons as outlined for the pool set-up. The correlation between water temperature data and dissolved $\mathrm{CO}_{2}$ data showed a weak negative value of -0.35

It is to be expected that the two locations selected for investigation in this mountain blanket peatland would generate different values with respect to the level of dissolved $\mathrm{CO}_{2}$. However, this study reveals a scale difference between these two settings, which are in relative terms spatially quite closely aligned. The relative rates of change in $\mathrm{CO}_{2}$ concentrations over the measurement period were greater in the pool waters when compared with the values recorded for the waters of the peat well (Fig. 10).

It is also significant to note the temperature component which has a significant influence in on the solubility of gas including $\mathrm{CO}_{2}$, shows a weak relationship with the actual values recorded. This clearly suggests that the process of $\mathrm{CO}_{2}$ solubility in the waters of the peatlands and its subsequent efflux and translocation through the catchment is likely to be controlled by a multiplicity of factors acting in concert.

\section{Discussion}

\subsection{Blanket peatland $\mathrm{CO}_{2}$ concentration profiles}

The profile of $\mathrm{CO}_{2}$ concentrations recorded for the peatland soil zone $\left(18,000-58,000 \mu \mathrm{mol} \mathrm{mol}^{-1}\right)$ was more than an order of magnitude greater than that recorded for the pool $\left(710-1560 \mu \mathrm{mol} \mathrm{mol}^{-1}\right)$ at the study site (Figs. 8 and 9). High variability has been reported in the literature for these concentrations in similar settings. Hamilton et al. (1994) reported $\mathrm{CO}_{2}$ concentrations ranging from 2 to 90 times atmospheric for boreal wetland ponds. Whitfield et al. (2010) suggest that such variability is likely to be a function of the morphology of the sample locations coupled with the extent of surface water pools and the surrounding vegetation community. Indeed, there is likely to be a higher level of heterotrophic and autotrophic respiration in the peat body compared with the situation prevailing in the pools. Additionally, water movement in blanket peatlands represents a significant aspect of their overall biogeochemical dynamics (Holden, 2005). Rezanezhad et al. (2016) report on the dual-porosity of peat which distinguishes a "mobile region" through which water, solutes and colloids move relatively easily,

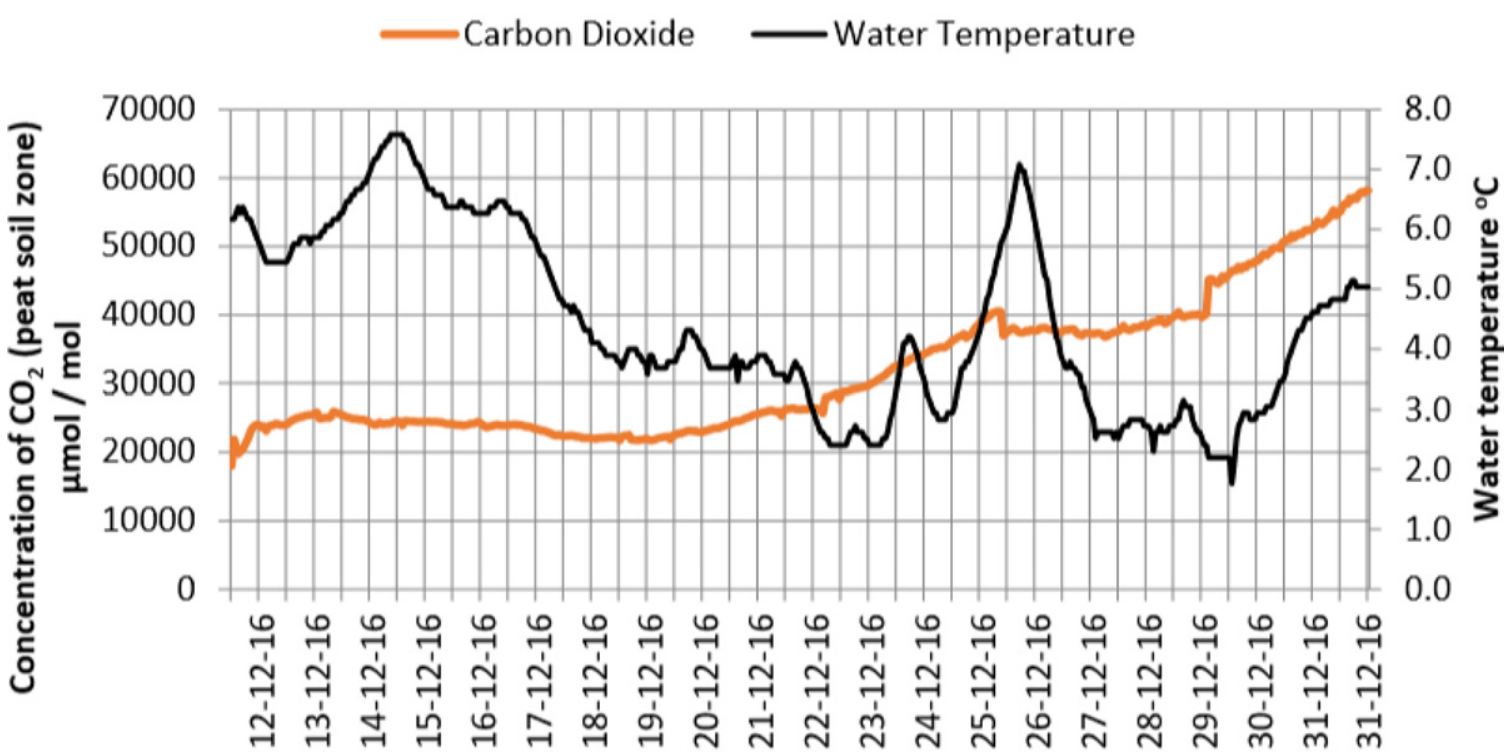

Fig. 9. Corrected $\mathrm{CO}_{2}$ concentration (peat soil condition) $\mu \mathrm{mol} \mathrm{mol}^{-1}$. 


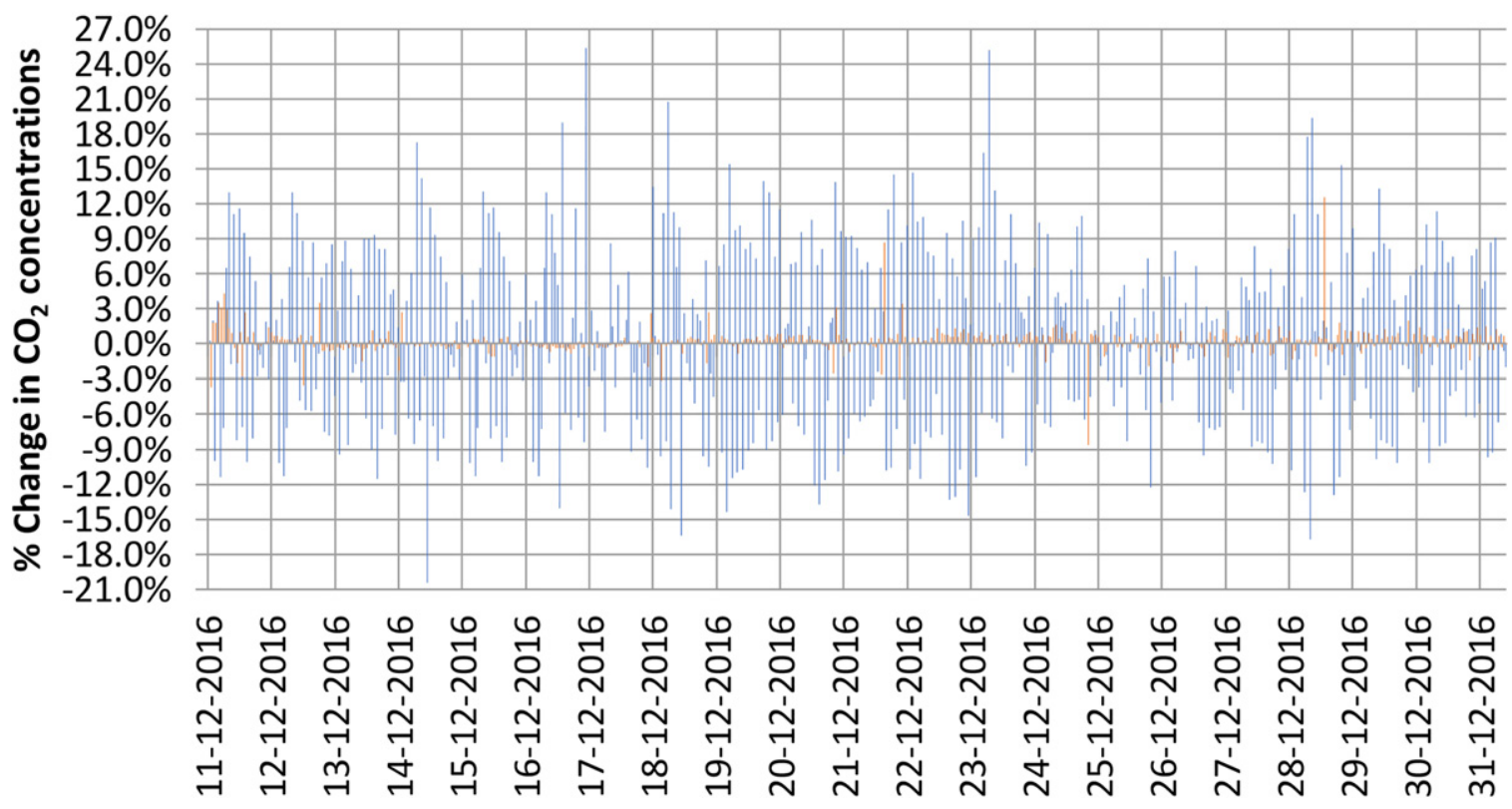

Fig. 10. Relative rates of change for the $\mathrm{CO}_{2}$ concentration between pool and peat waters.

and an "immobile region" with negligible fluid dynamics. It has been suggested that while advection through the open and connected pores, and matrix diffusion into and within closed pores are the dominant mechanisms controlling solute transport in peat, that only a relatively small number of studies have investigated the effects of the dual-porosity structure of peat on solute transport (Rezanezhad et al., 2016). Thus it is difficult to quantify this component in the reported $\mathrm{CO}_{2}$ values. However, in order to accommodate for this dynamic and to minimise its potential influence on measured $\mathrm{CO}_{2}$ values the selected study site was located on a mountain interfluve such that gravitational fluid inflow was minimal.

The water in blanket peatlands is typically in contact with, and thus influenced by the underlying mineral soil with the potential for associated inorganic and organic carbon $\left(\mathrm{CO}_{2}\right)$ enrichment which may add to the values reported in the peat soil zone. However, there is also considerable uncertainty over the local hydrodynamics within blanket peatlands and thus the potential contribution to carbon stocks from allochtonous sources (Holden and Burt, 2003). Noticeable about the pool $\mathrm{CO}_{2}$ concentrations is that they show relatively rapid short-term fluctuations when compared to the $\mathrm{CO}_{2}$ profile for the peat soil zone, which presents a much smoother profile (Figs. 8-10). Thus, this data suggests that the peat soil zone may have a much higher level of relative $\mathrm{CO}_{2}$ inertia and is less susceptible to short term rapid fluctuations. The significance of peat soil saturation and vegetation is well recognised in controlling the heterogeneous distribution of microbial habitats and activity (Rezanezhad et al., 2016). The peat soil $\mathrm{CO}_{2}$ flux observed has been measured in the water table below the surface vegetation yet this surface vegetation is relevant as it determines the nature of the detrital feedstock that accumulates as dead organic matter and forms the substrate for microbial activity. The peat soil zone in this study was situated at the transition between lawn and hummock communities and hence the underlying peat soil comprises a higher proportion of vascular plant detrital material, particularly close to the surface. The consequence of this is that underlying peat mass would have a higher fibrous content and an associated higher porosity value. This elevated near surface porosity has a direct bearing on local hydrodynamics and $\mathrm{O}_{2}$ supply at the microsite and is likely to be an important determinant in the elevated $\mathrm{CO}_{2}$ values recorded. This coupled with the potential advection of $\mathrm{CO}_{2}$, proximity of the water tableatmospheric boundary and relative thermal isolation of the microsite provide a context in which the elevated $\mathrm{CO}_{2}$ values recorded can be interpreted.

\subsection{Temperature response}

This study took place during the mid-winter season and accordingly temperatures were most likely to be close to their lowest values and the light levels were at their lowest values given that the study took place over the winter solstice. The temperature profiles for the air, water and soil components at the study site were recorded (Fig. 7). The driving thermal parameter is the air temperature (incident radiation being minimal) and accordingly it would be expected that the water and soil temperatures would follow the air temperature which ranged from $-3^{\circ} \mathrm{C}$ to $10^{\circ} \mathrm{C}$ over the study period. From an analysis of the data in Fig. 7 it is evident that the water temperature exhibited only moderate to weak correlation with the air temperature with a 
coefficient of 0.427 . This is somewhat expected given the length of the study or time frame involved and the fact that water has a higher specific heat capacity than air which produces a thermal lag with respect to changing air temperatures. This is not surprising given the mechanistic structure and physical relationships of air, water and soil in the blanket peatland system. It also reflects the multiplicity of other parameters within the system that influence water temperature including, solar radiation, relative humidity, wind speed, water depth, groundwater/matrix water inflow, and the thermal conductivity of the peat matrix material.

It has been well recognised that temperature is an important factor governing decomposition and that there is a general correlation between temperature values and $\mathrm{CO}_{2}$ generation in soil organic matter (Jauhiainen et al., 2014). In this respect respiration $Q_{10}$ values of circa 2 have been reported for peatlands (Johansson, 2010). Hence it is appropriate to examine the measured data for temperature and $\mathrm{CO}_{2}$ concentrations at the study site. As noted earlier, although air temperature is the principle source of thermal input to the peatland ecosystem, it is the mechanism by which this thermal energy is conveyed to the $\mathrm{CO}_{2}$ controlling processes that is important in controlling system outputs. Since water permeates the system and is the medium for $\mathrm{CO}_{2}$ transport and diffusion it is appropriate that the thermal character of this component is examined. Thus, the water temperature and $\mathrm{CO}_{2}$ concentrations for the pool and the peat soil zone were compared over the study period (Figs. 8 and 9). Comparing the data arrays from the pool set-up (Fig. 8) results in a weak positive correlation coefficient of 0.248 . However, when water temperature and $\mathrm{CO}_{2}$ values for the peat soil zone are evaluated the resultant correlation value is a weak negative value of -0.35 . It has already been recognised that $\mathrm{CO}_{2}$ and temperature do have a mechanistic association (Johansson, 2010). Thus, it is interesting to note the lack of correlation in the data sets. This suggests that more complex processes are at work in this ecosystem. Indeed, it has been suggested that unravelling the $\mathrm{CO}_{2}$ thermal feedback effect in blanket peatland ecosystems is particularly difficult, because the diverse range of organic compounds exhibit a wide range of kinetic properties, which determine the intrinsic thermal dynamics of their decomposition. Moreover, several environmental constraints obscure the intrinsic thermal dimensions of substrate decomposition which masks the actual controlling processes within the system (Davidson and Janssens, 2006). Beer et al. (2008) note that fermenting and methanogenic populations decompose the organic matter in a stepwise manner under a successive diminution of free energy. Methanogenic organisms utilise the products of fermentation or reduce $\mathrm{CO}_{2}$ with hydrogen $\left(\mathrm{H}_{2}\right)$ to form $\mathrm{CH}_{4}$ and $\mathrm{CO}_{2}$. The accumulation of $\mathrm{CO}_{2}$ and $\mathrm{CH}_{4}$ decreases the availability of free energy available to methanogens below threshold values of -25 to $-20 \mathrm{~kJ} \mathrm{~mol}^{-1}$ required for ongoing microbial substrate degradation (Beer et al., 2008). Hence further analysis of the $\mathrm{CO}_{2}$ flux dynamics needs to examine the dominance and dynamics of intermediate chemical species, and the stratified nature of $\mathrm{pH}$ variation, nutrient availability and the accumulation of toxins that limit respiration. Therefore, it will be necessary to examine other parameters of the system in order to develop a more insightful mechanistic understanding of the factors controlling $\mathrm{CO}_{2}$ concentrations. It is also worth noting that some of the $\mathrm{CO}_{2}$ response with respect to temperature may not reveal itself as the temperature range is simply too small. Added to this is the fact that the average temperature value is quite low averaging $4.4{ }^{\circ} \mathrm{C}$ and that this diminishes the thermal element in controlling the $\mathrm{CO}_{2}$ concentrations experienced. It may well be that at higher temperatures the correlation could be stronger. Nonetheless the results of this study suggest that other factors in the ecosystem are probably more dominant in controlling the values of $\mathrm{CO}_{2}$ in the peatland ecosystem or that the thermal component in the system is significantly affected by other biotic and even abiotic elements (Limpens et al., 2008) and underscores the need to view these systems as complex adaptive systems (Levin, 1998).

\subsection{Further research}

The carbon cycle of blanket peatlands is dependent on a complex of abiotic and biotic parameters and variables interacting in a multiplicity of different ways which consequently presents a significant challenge to the development of system understanding. There have been many attempts to develop system descriptions that address the challenge of this complexity. However, there are also many contrary views on the true significance of different functional processes and the reliability that can be attached to parameter values in these approaches (Tang et al., 2003; Parry et al., 2012).

This study suggests a role for a direct in situ continuous measurement strategy using non-dispersive infrared (NDIR) sensors in combination with a site architecture to evaluate $\mathrm{CO}_{2}$ concentrations and efflux in water. Such sensors have been applied to this task before (Johnson et al., 2010) but what has been developed here is a field design that allows their use in soil-pore water and pond water analysis in blanket peatlands over extended periods of time. This design provides enhanced reliability in that the sensor maintains a constant position in the fluctuating water table. However, there remains a measure of uncertainty attached to the source of $\mathrm{CO}_{2}$ as the flux measures may include diffusion from deeper layers and the current approach provides limited vertical temperature profile. Addressing this will require closer examination of peat stratification, temperature variation with depth and $\mathrm{CO}_{2}$ source dynamics within the site and should form the basis for a more sophisticated expansion of this approach. Understanding the temporal and spatial pattern of system parameters is crucial to a more accurate assessment of the true $\mathrm{CO}_{2}$ dynamics of these important ecosystems. Additionally, the importance of understanding wintertime fluxes of $\mathrm{CO}_{2}$ in the northern hemisphere has been well acknowledged (Aurela et al., 2002; Roehm and Roulet, 2003) yet data on these dynamics is fragmented. This work provides a methodological template that facilitates the development of new initiatives to address questions on the relationship of environmental parameters with the scale 
and magnitude of temporal and spatial variability of $\mathrm{CO}_{2}$ in highland and remote blanket peatlands.

\subsection{Conclusion}

This study sought to investigate the soil pore water and pool water temporal variability of $\mathrm{CO}_{2}$ concentrations in an Irish mountain blanket peatland and to explore the hydrological pathways that promote storage, transport and efflux of carbon. This was addressed through the development of a novel implementation system for in situ longitudinal monitoring of $\mathrm{CO}_{2}$ concentrations in a pool and nearby peat soil zone. Given that the study occurred in the mid-winter period it was expected that photosynthetic $\mathrm{CO}_{2}$ contributions would be minimal and that most of the $\mathrm{CO}_{2}$ measured was from older sources. The $\mathrm{CO}_{2}$ concentrations recorded showed significant differences between the pool waters and the peat soil zone. It was interesting to note that the relatively weak relationship between temperature and $\mathrm{CO}_{2}$ values. Indeed, this is consistent with some other findings which report weak links between soil $\mathrm{CO}_{2}$ efflux and temperature (Tang et al., 2003). This suggests that other processes have an important role to play in generating the values recorded including plant physiological and phenological factors, and that it would be unwise to draw too strong an interpretation from the measured data regarding the relationship between water temperature and the $\mathrm{CO}_{2}$ values. The lack of correlation also suggests that the blanket peatland ecosystem behaves as a complex system, where key uncertainties remain regarding the existence of perturbation thresholds, the relative strengths of $\mathrm{CO}_{2}$ feedback, the role of hydrodynamics, ecosystem structure and function, and trace gas biogeochemistry. A novel dimension that emerges from this study is the distinction between total ecosystem respiration and soil microbial respiration. Since this study occurred in the deep mid-winter period and the peat soil $\mathrm{CO}_{2}$ effluxes were measured just below the surface of the water table, these resulting $\mathrm{CO}_{2}$ effluxes are more closely aligned with the soil microbial activity. This is a significant issue in peatland biogeochemistry and underscores the important role of peat water table $\mathrm{CO}_{2}$ efflux measurements in winter (Zhang et al., 2005). As such these results provide an important input to the spatial disaggregation of the $\mathrm{CO}_{2}$ budget across ponds and peat soils within a blanket peatland in winter. However, building a deeper understanding of the carbon dynamics within this ecosystem will require further analysis of the system components, the nature of their interaction through the mediation of powerful and frequently also complex causal networks, and the recognition of the associated emergent properties. This is a prerequisite to a more holistic and deeper ecological appreciation of the role of these significant ecosystems within the biosphere.

\section{Conflict of interest}

None declared.

\section{Ethical statement}

Authors state that the research was conducted according to ethical standards.

\section{Acknowledgements}

None.

\section{Funding body}

None.

\section{References}

Aalen, F.H.A., Whelan, K., Stout, M. (Eds.), 2011. Atlas of the Irish Rural Landscape. 2nd ed. Cork University Press, Cork, Ireland.

Amundson, R., 2001. The carbon budget in soils. Annu. Rev. Earth Planet. Sci. 29, 535-562, http://dx.doi.org/10.1146/annurev.earth.29.1.535.

Aurela, M., Laurila, T., Tuovinen, J.-P., 2002. Annual $\mathrm{CO}_{2}$ balance of a subarctic fen in northern Europe: importance of the wintertime efflux. J. Geophys. Res. 107

Baehr, M.M., DeGrandpre, M.D., 2004. In situ $\mathrm{pCO}_{2}$ and $\mathrm{O}_{2}$ measurements in a freshwater lake during turnover and stratification: observations and a model. Limnol. Oceanogr. 49, 330-340.

Battin, T.J., Kaplan, L.A., Findlay, S., Hopkinson, C.S., Marti, E., Packman, A.I., Newbold, J.D., Sabater, F., 2008. Biophysical controls on organic carbon fluxes in fluvial networks. Nat. Geosci. 1 (2), 95-100, http:// dx.doi.org/10.1038/ngeo101.

Beer, J., Lee, K., Whiticar, M., Blodau, C., 2008. Geochemical controls on anaerobic organic matter decomposition in a northern peatland. Limnol. Oceanogr. 53 (4), 1393-1407.

Bodmer, P., Heinz, M., Pusch, M., Singer, G., Premke, K., 2016. Carbon dynamics and their link to dissolved organic matter quality across contrasting stream ecosystems. Sci. Total Environ. 553, 574-586, http://dx.doi.org/10.1016/j.scitotenv.2016.02.095.

Bullock, C.H., Collier, M.J., Convery, F., 2012. Peatlands, their economic value and priorities for their future management - the example of Ireland. Land Use Policy 29 (4), 921-928.

Claire Horner-Devine, M., Leibold, M.A., Smith, V.H., Bohannan, B.J., 2003. Bacterial diversity patterns along a gradient of primary productivity. Ecol. Lett. 6 (7), 613-622.

Cole, J.J., Prairie, Y.T., Caraco, N.F., McDowell, W.H., Tranvik, L.J., Striegl, R.G., Duarte, C.M., Kortelainen, P., Downing, J.A., Middelburg, J.J., Melack, J., 2007. Plumbing the global carbon cycle: integrating inland waters into the terrestrial carbon budget. Ecosystems 10, 172-185.

Choi, T.V.D.I.Y., Son, Y.S., 2011. A review on non-dispersive infrared gas sensors. Atmos. Chem. Phys. 11, 6083-6114, http://dx.doi.org/ 10.1016/j.snb.2016.03.040.

Conaghan, J., Douglas, C., Grogan, H., O’Sullivan, A., Kelly, L., Garvey, L., Van Doorslaer, L., Scally, L., Dunnells, D., Wyse Jackson, M., Goodwillie, R., Mooney, E., 2000. Distribution, Ecology and Conservation of Blanket Bog in Ireland, a Synthesis of the Reports of the Blanket Bog Surveys Carried Out Between 1987 and 1991 by the National Parks \& Wildlife Service. Enviroscope Environmental Consultancy, Galway, Ireland.

Crawford, J.T., Lottig, N.R., Stanley, E.H., Walker, J.F., Hanson, P.C., Finlay, J.C., Striegl, R.G., 2014. $\mathrm{CO}_{2}$ and $\mathrm{CH}_{4}$ emissions from streams in a lakerich landscape: patterns, controls, and regional significance. Glob. Biogeochem. Cycles 28 (3), 197-210.

Davidson, E.A., Janssens, I.A., 2006. Temperature sensitivity of soil carbon decomposition and feedbacks to climate change. Nature 440 (7081), $165-173$.

Dinsmore, K.J., 2008. Atmosphere-Soil-Stream Greenhouse Gas Fluxes from Peatlands. (Ph.D. thesis)University of Edinburgh, Edinburgh, United Kingdom.

Dinsmore, K.J., Smart, R.P., Billett, M.F., Holden, J., Baird, A.J., Chapman, P.J., 2011. Greenhouse gas losses from peatland pipes: a major pathway for loss to the atmosphere? J. Geophys. Res. 116, G03041, http:// dx.doi.org/10.1029/2011JG001646.

Fasching, C., Behounek, B., Singer, G.A., Battin, T.J., 2014. Microbial degradation of terrigenous dissolved organic matter and potential consequences for carbon cycling in brown water streams. Sci. Rep. 4 (4981), http://dx.doi.org/10.1038/srep04981.

Feehan, J., O’Donovan, G., 1996. Bogs of Ireland. Environmental Institute, University College Dublin, Dublin.

Hammond, R.F., 1981. The Peatlands of Ireland. An Foras Taluntais, Dublin.

Hamilton, J.D., Kelly, C.A., Rudd, J.W.M., Hesslein, H., Roulet, N.T., 1994. Flux to the atmosphere of $\mathrm{CH}_{4}$ and $\mathrm{CO}_{2}$ from wetland ponds on the Hudson Bay Lowlands (HBLs). J. Geophys. Res. 99, 1495-1510. 
Hannigan, E., Mangan, R., Kelly-Quinn, M., 2011. Evaluation of the success of mountain blanket bog pool restoration in terms of aquatic macroinvertebrates. Biol. Environ.: Proc. R. Irish Acad. 95-105.

Holden, J., Burt, T.P., 2003. Hydrological studies on blanket peat: the significance of the acrotelm-catotelm model. J. Ecol. 91 (1), 86-102.

Holden, J., 2005. Peatland hydrology and carbon release: why small-scale process matters. Philos. Trans. R. Soc. Lond. A: Math. Phys. Eng. Sci. 363 (1837), 2891-2913.

Hope, D., Dawson, J.J.C., Cresser, M.S., Billett, M.F., 1995. Method for measuring free $\mathrm{CO}_{2}$ in upland streamwater using headspace analysis J. Hydrol. 166, 1-14.

Jauhiainen, J., Kerojoki, O., Silvennoinen, H., Limin, S., Vasander, H., 2014. Heterotrophic respiration in drained tropical peat is greatly affected by temperature - a passive ecosystem cooling experiment. Environ. Res. Lett. 9 (10), 105013

Johansson, L., 2010. Temperature Sensitivity of Decomposition in a Boreal Mixed Mire in Northern Sweden. (M.Sc. Thesis)Water and Environmental Studies, Department of Thematic Studies, Linköpings Universitet.

Johnson, L.C., Damman, A.W.H., 1991. Species-controlled Sphagnum decay on a South Swedish raised bog. Oikos 61, 234-242.

Johnson, M.S., Billett, M.F., Dinsmore, K.E., Jassal, R.S., 2010. Direct and continuous measurement of dissolved carbon dioxide in freshwater aquatic systems - method and applications. Ecohydrology 3, 68-78.

Kling, G.W., Kipphut, G.W., Miller, M.C., 1991. Arctic lakes and streams as gas conduits to the atmosphere - implications for tundra carbon budgets. Science 251 (4991), 298-301.

Labadz, J., Allott, T., Evans, M., Butcher, D., Billett, M., Stainer, S., Yallop, A., Jone, P., Innerdale, M., Harmon, N., Maher, K., Bradbury, R., Mount, D. O’Brien, H., Hart, R., 2010. Peatland Hydrology - Draft Scientific Review IUCN UK Peatland Programme Commission of Inquiry on Peatlands. Natural England \& Severn Trent Water.

Laiho, R., 2006. Decomposition in peatlands: reconciling seemingly contrasting results on the impacts of lowered water levels. Soil Biol. Biochem. 38, 2011-2024.

Law, B.E., Falge, E., Gu, L.V., Baldocchi, D.D., Bakwin, P., Berbigier, P., Davis, K., Dolman, A.J., Falk, M., Fuentes, J.D., Goldstein, A., 2002. Environmental controls over carbon dioxide and water vapor exchange of terrestrial vegetation. Agric. Forest Meteorol. 113 (1), 97-120.

Leith, F.I., Dinsmore, K.J., Wallin, M.B., Billett, M.F., Heal, K.V., Laudon, H., Oquist, M.G., Bishop, K., 2015. Carbon dioxide transport across the hillslope-riparian-stream continuum in a boreal headwater catchment. Biogeosciences 12 (6), 1881-1892.

Levin, S.A., 1998. Ecosystems and the biosphere as complex adaptive systems. Ecosystems 15, 431-436

Le Quéré, C., Raupach, M.R., Canadell, J.G., Marland, G., Bopp, L., Ciais, P., Conway, T.J., Doney, S.C., Feely, R.A., Foster, P., Friedlingstein, P., 2009. Trends in the sources and sinks of carbon dioxide. Nat. Geosci. 2 (12), 831-836.

Limpens, J., Berendse, F., Blodau, C., Canadell, J.G., Freeman, C., Holden, J., Roulet, N., Rydin, H., Schaepman-Strub, G., 2008. Peatlands and the carbon cycle: from local processes to global implications-a synthesis. Biogeosciences 5, 1475-1491, http://dx.doi.org/10.5194/bg-5-14752008.

Lindsay, R., 1995. Bogs: The Ecology, Classification and Conservation of Ombrotrophic Mires. Scottish Natural Heritage, Morton Ward Association, Edinburgh, Scotland.

Met Eireann, 2017a. http://www.met.ie/climate-ireland/rainfall.asp (accessed 23.12.17)

Met Eireann, 2017b. http://www.met.ie/climate/monthly-data.asp (accessed 23.12.17).

National Parks and Wildlife Service, 2017. https://www.npws.ie/ (accessed 23.12.17).

Neal, C., House, W.A., Down, C., 1998. An assessment of excess carbon dioxide partial pressures in natural waters based on $\mathrm{pH}$ and alkalinity measurements. Sci. Total Environ. 210-211, 173-185.

OSI, 2017. https://www.osi.ie/ (accessed 23.12.17)

Otte, M.L. (Ed.), 2003. Wetlands of Ireland. Distribution, Ecology, Uses and Economic Value. University College Dublin Press, Dublin, Ireland.
Parry, L.E., Charman, D.J., Noades, J.P.W., 2012. A method for modelling peat depth in blanket peatlands. Soil Use Manag. 28 (4), 614-624.

Plummer, L.N., Busenberg, E., 1982. The solubilities of calcite, aragonite and vaterite in $\mathrm{CO}_{2}-\mathrm{H}_{2} \mathrm{O}$ solutions between 0 and $90^{\circ} \mathrm{C}$, and an evaluation of the aqueous model for the system $\mathrm{CaCO}_{3}-\mathrm{CO}_{2}-\mathrm{H}_{2} \mathrm{O}$. Geochim. Cosmochim. Acta 46 (6), 1011-1040.

Raymond, P.A., Hartmann, J., Lauerwald, R., Sobek, S., McDonald, C., Hoover, M., Butman, D., Striegl, R., Mayorga, E., Humborg, C., Kortelainen, P., Durr, H., Meybeek, M., Ciais, P., Guth, P., 2013. Global carbon dioxide emissions from inland waters. Nature 503 (7476), 355-359, http://dx.doi.org/10.1038/nature12760.

Rezanezhad, F., Price, J.S., Quinton, W.L., Lennartz, B., Milojevic, T., Van Cappellen, P., 2016. Structure of peat soils and implications for water storage, flow and solute transport: a review update for geochemists. Chem. Geol. 429, 75-84

Roehm, C.L., Roulet, N.T., 2003. Seasonal contribution of $\mathrm{CO}_{2}$ fluxes in the annual C budget of a northern bog. Glob. Biochem. Cycles 17 (1) .

Ruhala, S.S., Zarnetske, J.P., 2017. Using in-situ optical sensors to study dissolved organic carbon dynamics of streams and watersheds: a review. Sci. Total Environ. 575, 713-723.

Schulze, E.D., Freibauer, A., 2005. Environmental science - carbon unlocked from soils. Nature 437 (7056), 205-206.

Scott, H.D., 2000. Soil Physics: Agricultural and Environmental Applications. Iowa State University Press, Ames, IA.

Sweeney, J., 2014. Regional weather and climates of the British Isles - Part 6: Ireland. Weather 69, 20-27, http://dx.doi.org/10.1002/wea.2230.

Tang, J., Baldocchi, D.D., Qi, Y., Xu, L., 2003. Assessing soil $\mathrm{CO}_{2}$ efflux using continuous measurements of $\mathrm{CO}_{2}$ profiles in soils with small solidstate sensors. Agric. Forest Meteorol. 118 (3), 207-220.

Turner, E.K., Worrall, F., Burt, T.P., 2013. The effect of drain blocking on the dissolved organic carbon (DOC) budget of an upland peat catchment in the UK. J. Hydrol. 479, 169-179, http://dx.doi.org/10.1016/j.jhydrol.2012.11.059.

Uhlmann, D., Paul, L., Hupfer, M., Fischer, R., 2011. Lakes and Reservoirs. Treatise on Water Science. Elsevier, Amsterdam, pp. 157-213.

Vaisala, 2012. How to Measure Carbon Dioxide. http://www.vaisala.com/ Vaisala\%20Documents/Application\%20notes/CEN-TIA-ParameterHow-to-measure-CO2-Application-note-B211228EN-A.pdf (accessed 23.12.17).

Vaisala, 2013. GMM220 Carbon Dioxide Modules for Demanding OEM Applications. http://www.vaisala.com/Vaisala\%20Documents/ Brochures\%20and\%20Datasheets/ GMM220_Datasheet-B210856EN-E.pdf (accessed 23.12.17).

Wallin, M.B., Oquist, M.G., Buffam, I., Billett, M.F., Nisell, J., Bishop, K.H. 2011. Spatiotemporal variability of the gas transfer coefficient $\left(\mathrm{KCO}_{2}\right)$ in boreal streams: implications for large scale estimates of $\mathrm{CO}_{2}$ evasion. Glob. Biogeochem. Cycles GB3025, http://dx.doi.org/ 10.1029/2010GB003975.

Wallin, M.B., Grabs, T., Buffam, I., Laudon, H., Ågren, A., Öquist, M.G., Bishop, K., 2013. Evasion of $\mathrm{CO}_{2}$ from streams - the dominant component of the carbon export through the aquatic conduit in a boreal landscape. Glob. Change Biol. 19 (3), 785-797.

Whitfield, C.J., Aherne, J., Baulch, H.M., 2011. Controls on greenhouse gas concentrations in polymictic headwater lakes in Ireland. Sci. Total Environ. 410-411, 217-225.

Whitfield, C.J., Seabert, T.A., Aherne, J., Watmough, S.A., 2010. Carbon dioxide supersaturation in peatland waters and its contribution to atmospheric efflux from downstream boreal lakes. J. Geophys. Res. Biogeosci. 115 (G4)

Worrall, F., Reed, M., Warburton, J., Burt, T., 2003. Carbon budget for a British upland peat catchment. Sci. Total Environ. 312 (1-3), 133-146.

Yang, R., Chen, B., Liu, H., Liu, Z., Yan, H., 2015. Carbon sequestration and decreased $\mathrm{CO}_{2}$ emission caused by terrestrial aquatic photosynthesis: insights from diel hydrochemical variations in an epikarst spring and two spring-fed ponds in different seasons. Appl. Geochem. 63 (3), 248-260.

Zhang, J.B., Song, C.C., Yang, W.Y., 2005. Cold season $\mathrm{CH}_{4}, \mathrm{CO}_{2}$ and $\mathrm{N}_{2} \mathrm{O}$ fluxes from freshwater marshes in northeast China. Chemosphere 59 (11), 1703-1705. 